Kohl: a Journal for Body and Gender Research

Vol. 6, No. 3 (Winter 2020)

\title{
Suture Fragmentations - A Note on Return
}

Sarona Abuaker Bedwan 


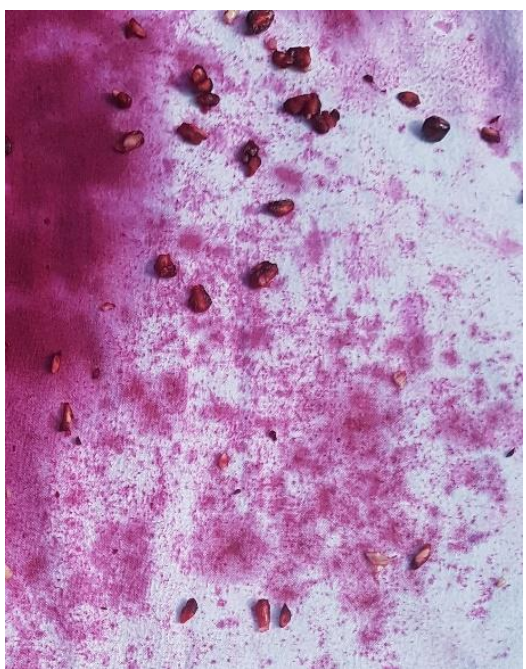

"To stand with us in this circle with its centre everywhere and its circumference now/here is to be under a spell. A pleasure to meet you here: enchanted"1



"To be orientated around something is not so much to take up that thing, as to be taken up by something, such that one might even become what it is that is 'around'"2

Shortly after finishing an essay exploring how Palestinian's abilities to produce aesthetics inherently carves new spaces to resist Israeli settler colonialism, I visited Basma Alsharif's exhibition The Gap Between Us at the Mosaic Rooms in London. ${ }^{3}$ It was Alsharif's first independent UK exhibition, comprised of three pieces originating from different moments in her practice. Overlaying a multiplicity of images and sounds from original film footage taken from different locations she visited, Alsharif stitches together rich tapestries of reimagined spaces and times as an intimate navigation through her ideas of what Palestinian imagination and memory re/building can look like as a Palestinian in diaspora. Filming in France, Italy, California, the Gaza Strip, Malta, and Athens, she weaves aesthetics familiar to the Palestinian national struggle amongst a backdrop of unfamiliar landscapes, and interrogates the elasticity of what is constituted as familiar Palestinian cultural forms by challenging the audience and herself with the question, "what do you do when civilization has failed you? What happens if the Right of Return is never granted - what will this mean for Palestinians?"4

Moving from piece to piece, Alsharif's unflinching questions on return, memory re/building and futuristic aesthetic reconfigurations have followed and not left me since. Emerging from the collision of her cultural forms constituting as Palestinian expressions was not only a reshaped understanding of resistance, but a shift in how to engage with and produce Palestine and Palestinian's relationship with diaspora. The conditions involved in experiencing displacement, nation-state building, and identity formation are not unique to Palestinians or to the Palestinian national struggle. These themes, however, have become synonymous to Palestinian ontology due to their repetition and juxtaposition within Palestinian cultural production as strategic methods to evoke indigenous claims in the face of ongoing Israeli settler colonialism.

\footnotetext{
1 Shin, S. and Tamás, R. 2018. Spells: $21^{\text {st }}$ - Century Occult Poetry. Ignota.

2 Ahmed, S. 2006. Queer Phenomenology. Duke University Press Books.

${ }^{3}$ Alsharif, B. 2018. The Gap Between Us. [Film Footage] London: The Mosaic Rooms.

4 Basma Alsharif by Aily Nash. 2015. BOMB. [online] Available at: https://bombmagazine.org/articles/basma-alsharif/.
} 
Necessitating the physical and cultural erasure of the indigenous, settler colonialism "comes with the intention of making a new home on the land, a homemaking that insists on settler sovereignty over all things in their new domain." 5 The reality of dispossession impacts Palestinians' ways of engaging, moving in, and experiencing Palestine on the physical realm of being able to access the land. Out of this physical uprooting, and the response to it, is a production of Palestinian-ness tied to a "place-bound definition (which) focuses on return, and home is defined as from where one came."6 Returning to Palestine functions as not only the point of origin for how Palestinians come to identify themselves, but as an activator for aesthetic production as it reflects conditions of exile. Expressions of return in all its dimensions have become the prevailing cultural discourse for engagement with Palestine and Palestinian-ness, especially for Palestinians in diaspora. When Palestinians' common capacity to engage with themselves exists mainly through this framework, how does this shape Palestinian diasporic ontologies? What happens when this concept of return is no longer the exclusive departure point?

Return

"to come back or go back to a place or person/architecturally continue (a wall) in a changed direction, especially at right angles"7

The notion of return, or returning, glimmers ripplingmovements.

This is a poem colonizers'

will

cut

their hands on

chronic wounds



splintering

Return is inherently an experiment in phenomenology; to go or come back is a beckoning of how to arrive. Alsharif's gaps directs the viewer to stitched spatialities and temporalities in order to interrogate return. It is here, in this moment of being re-turned to experience a return by her films I found what was relegated to the background of my life but I was always----x

$$
x------ \text { arriving to-------X }
$$

Palestinian-ness as a queer dimension and the possibilities of queering return--- $x$

5 Tuck, E. and Yang, K. 2012. Decolonization Is Not A Metaphor. Decolonization: Indigeneity, Education \& Society, [online] 1(1), pp.1-40. Available at: https://jps.library.utoronto.ca/

6 Peteet, J. 2007. Problematizing a Palestinian Diaspora. International Journal of Middle East Studies, 39(04), pp.121.

7 "Definition of RETURN." 2020. Merriam-Webster.Com. https://www.merriam-webster.com/dictionary/return. 


\section{Arriving \\ involves questions \\ timing, space, direction.}

Can we arrive, recognize we are arriving

if it is not thought out? It is a question of being in

a certain order - one that defies settler-colonial ordering.

To arrive to a place not on the map means thinking beyond what we see

pushing my body and vision in different, multiple ways to create new shapes, forms of thought.

We keep moving

I hear her

he didn't

fast

throw the
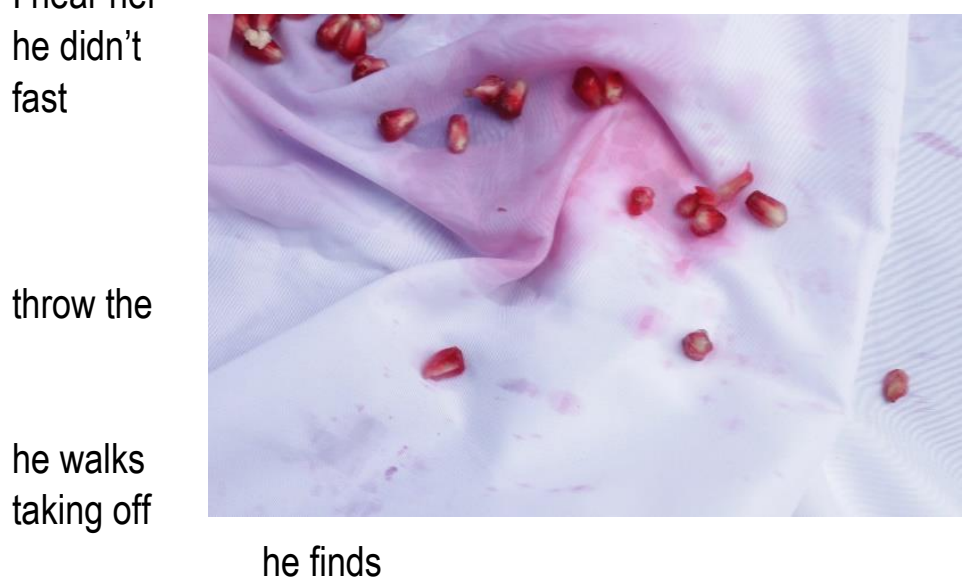

his skin comes off. say

roll down his window

enough to

Molotov.

$$
\mathrm{Re} /(0) \text { pen }
$$

from Lebanon to Syria

his socks

"Becoming reoriented

which involves the disorientation of encountering the world differently, made me wonder about orientation and how much 'feeling at home' or knowing which way we are facing is about the making of worlds"8

Alsharif's pieces spoke to a queerness already present; I was able to recognize the beats, rhythms, sutured landscapes, and disorientations for they mirrored, resonated with my own. Queerness of/being out of place in (diaspora), whilst pointing to queerness in Palestinian-ness. Her films made me think of how my experience of inheriting a homeland with a certain direction towards it, with a certain nature of relationality; to be Palestinian in many ways is to be constituted as an "unnatural" 9 occurrence for it pushes back against a hegemonic narrative reproducing Israel's settler-colonial epistemologies.

${ }^{8}$ Ahmed 2006.

9 Seymour, N. 2013. Strange Natures: Futurity, Empathy, And The Queer Ecological Imagination. 


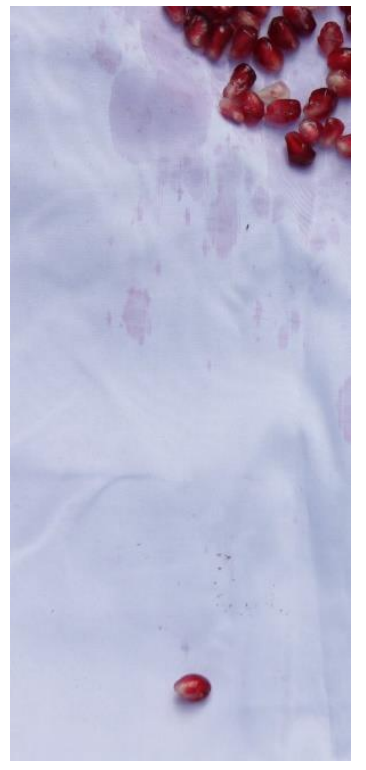

Without our ancestor's

masks (what are they?)

To be "off the map" is to embody uncharted territory, alien, not realized, not true. With lines on maps and countries carved as though they are as natural tectonic plate shifts, Palestinian-ness has been affixed in a certain direction, rooted in a certain force due to ongoing erasure and seeking a return.

We don't scatter

we are

elastic

stretching

beyond

their wildest dreams

Queerness here means the processes and acts of re-orienting return in relation to times, spaces, us. Return has always then, been conceived as "unnatural" for it is a practice of making an order beyond the state-sanctioned order which we live today, a "capitalist domestication"1 and settler-colonial regimes. $\varphi$ propose return as practice; queering return so it re-aligns with orientations of possibility, a way of directing through future-thinking. Return as spatial occurrences. How does queer phenomenology help us think about living return in different spaces and being re-turned in spaces? It is an inching "towards," and I want to think about what moving a towards and where that towards may be, to retexturize the feel of life

\section{we shape ourselves \\ with the force \\ of each other}

carve new spaces and times

wringing out

sea water

I am moved to queer return as a possibility of occurring and being encountered in many places for I am moved by it in a multiplicity of spaces, times, touches, gestures and articulations. This piece is an attempt to start re-directing, gathering my bearings and senses, only to return to them back to you as a reader and see what takes shape in this exchange. Creating new forms means moving, taking other directions and making new movements. There are specificities to how return gathers itself around me, and my intention is to highlight who is able to face return. There are tensions in the particularities of facing return one way for it is not one dimension or position. This is also an experiment in relationalities.

I am arriving in return/its multiplicity of dimensions.

1 lbid. 
Return(ing) is acknowledging and grappling absences; the familiar conditions which have been producing effects on Palestinians take shape by becoming unnoticed in their iterabilities. Understandings of return are mainly produced by perceptions, touch, articulations, and movements embodying reaching for a location. I use queer phenomenology in attempt to re-turn us around return to show the queerness of this endeavor, to show the queerness of Palestinian-ness; to show how the shapes of returns are generated by how we are coming to be and the conditions of arrivals. By facing return as only one-way, perhaps I am erasing other ways of looking at return; perhaps bringing forth return to show how it exists in a multiplicity of spaces and not defined/constrained to a perception shaped by the very system which blocks a particular arrival can be an exercise of shedding light on the nearness of return(ing). It is a way of world-making through new movements and senses. I want to change the feeling of return by re(turn)ing the possibilities of where return arrives, can be found, and can be touched.

Categorizing strictly through the nation-state has become an atmospheric experience developing and shaping our senses of the world for it lends itself as an inherent departure point for how people imagine themselves, and has become the only legitimate way of conceptualizing oneself. Legitimate here means the way in which hegemonic structural systems come to envelope one's aura through their recognizability of nation-ness and belonging to a state. Being Palestinian in many ways is queer due to the multiple dimensions I occupy - past, present, future, to not be recognized by states, inheriting a homeland without being in it. I am embodying an encapsulation of times, spaces, legacies and fragments. These fragmentations are a result of the establishment of Israel in 1948 "resulting in the devastation of Palestinian society. At least 80 percent of the Palestinians who lived in the major part of Palestine upon which Israel was established - more than 77 percent of Palestine's territory - became refugees." 1 The Nakba, catastrophe, simultaneously induced an uprooting in common Palestinian senses and expression. It is for this reason that I use fragmentation as a form for writing this piece.

\author{
the children \\ of those who were expelled \\ were colors. \\ Each one imbued \\ turning to each other and say \\ what if we were there \\ at the same time \\ together
}

\footnotetext{
1 Abu-Lughod, L. and Sa'di, A. 2007. Nakba: Palestine, 1948, and the Claims of Memory (Cultures of History). New York: Columbia University Press, pp.1-24.
} 
Settler-colonialism ruptures the cultivated by the indigenous to spaces splinter and become from oral narrativization to time and spaces which were in forms, textures, gestures, - it is experiencing shock and level.

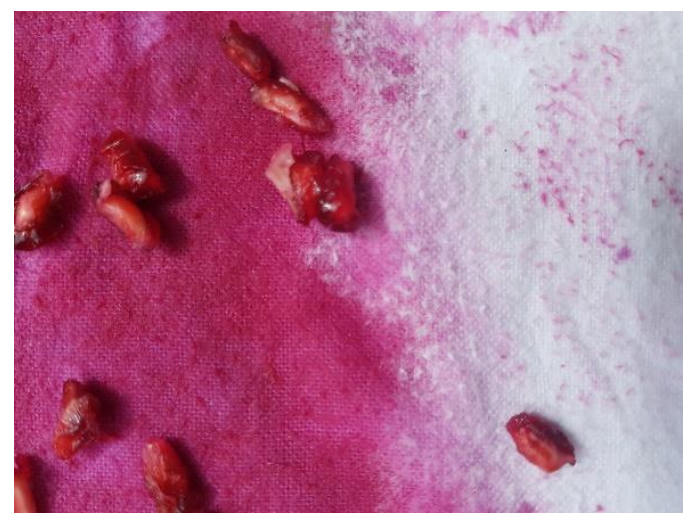

forms of times and spaces the land; these times and carried in different ways, cultural production. The violently uprooted change tongue, memory and touch disorientation on every

The creation and maintenance of Israel relies on the erasure of sensory experiences and understandings constituting Palestinian-ness. Erasure of sensory experiences, being able to locate oneself occurs

multiple

(sometimes dehiscent $\mathrm{i} \mid$ close| the stitches find them re/(o)pened tissue replaces dermis as epidermis in motion biochemical immunity)

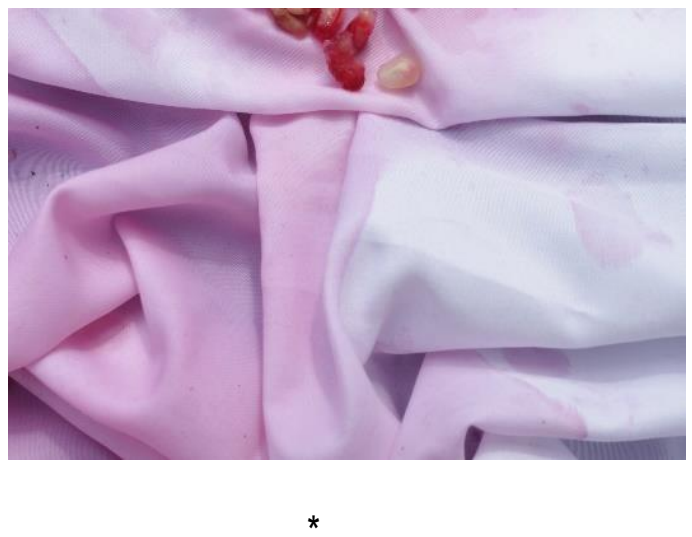

levels.

Settler-colonial erasure involves the unbinding of lines drawn around and, on the surfaces, which come to be felt as fact and knowledge; a violent systematic deliberate targeting to unravel what gives form to our lives. From re-drawing lines on a map, constituting written, textual forms as more "valid" than oral forms narrativizing experiences, freezing Palestinian bank accounts, stealing literature, films and images, to home demolitions and expulsions. Israeli settler-colonialism, like other examples of settler-colonialism, embodies how colonial state-building practices relies on the literal and aesthetic re-orientating of the indigenous.

Taking the "desert to make it bloom," a common trope emerging from Israeli settler colonial Soviet style posters, ${ }^{1}$ showing from a birds-eye-vie?v a lush valley sunken by the weight of happy, well-fed and cultivated trees meant to be representing Jaffa. Each tree bright, carrying engorged ripe sun-blasted oranges with a hand reaching towards the orange, a hand outstretched ready and eager to pick the fruity

1 Sivan, E. 2009. Jaffa, The Orange's Clockwork. Video. 
gem the land produced, for the land is grateful that a civilizing force has swept over it. The force is often embodied through the figure represented as a woman, smiling coyly as she picks the oranges for it is not only produce she is gathering, she is also producing lines of power and being received in certain directions solidifying the making of Israel.

As said woman picks oranges, lines appear into the land where homes once were - - - straightening lines, where the native homes embodying the "perversion," the "queerness," the "odd" ways in which the native inhabits the space. The being of Palestinian-ness in a space transformed into a threat to the state-building order; to be Palestinian embodied a direction of not just "backwards" but of being bent towards an idea, a physical discomfort for the new state because it was and continues to be a body that takes up space and in taking up space produces a shape which is not desired.

"The contemporary history of the Palestinians turns on a key date: 1948. That year, a country and its people disappeared from maps and dictionaries... 'The Palestinian people does not exist,' said the new masters, and henceforth the Palestinians would be referred to by general, conveniently vague terms, as either 'refugees,' or in the case of a small minority that had managed to escape the generalized expulsion, 'Israeli Arabs.' A long absence was beginning"1

Palestinian-ness became a being that was outside of the state logic. And as this line of thinking follows, we emanate a queerness for "when bodies 'arrive' that don't extend the lines already extended by spaces, then those spaces might even appear 'slantwise' or 'oblique'."1

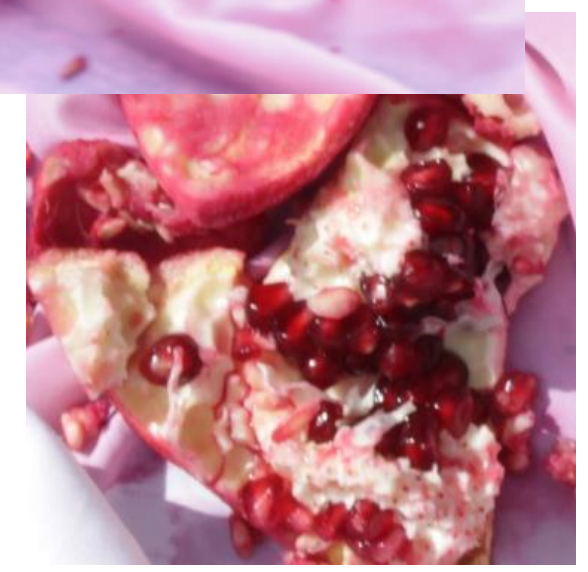

The length of time maintaining expulsions, and how dominance is re-asserted through the settler-colonial apparatus, whether here or there, accumulate and matter. Forms of dominance by Israel are expressed through the ability to create distances. Return is mainly approached as a thing which must appear only because it is perceived as a moment that has been blocked from its entry. Distance is not only a physical separation. Distances are not composed of matters which end when the separation ends, or when a recognized form of arrival arrives. It takes work to illuminate and thrive amidst gaps and spaces - but what about the matters at hand which we re-turn to do the work of return(ing) towards these openings and fragments? If return(ing) will take on the shapes of the conditioning from our bodies, who will be the ones who shape our pasts/presents/futures? The Nakba did not end; it only continues to devastate in re-fashioned ways.

1 Abu-Lughod and Sa'di 2007. 3

1 Ahmed 2006. 
It is here I intervene in a form of return. I want to turn now to look at the matter return can be/is made of. This attempt of thinking through return is an invitation to think about what matters about ourselves. The stuff of situating, measuring, arriving, leaving to and in around/ourselves.

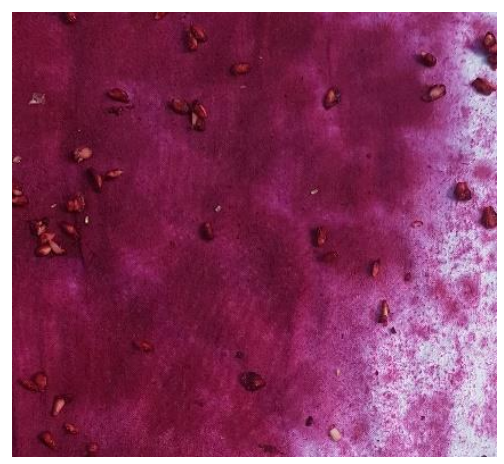

Return is an embodiment of labour and work - who is taking it upon themselves to ensure return emerging? Writing this piece is a form of labour. I am suggesting return(ing) can be/ is composed of such matters, such labours at hand. There is a question of the value of looking at how these navigations matter at all, especially to return(s). The value of tensions, unfurling them, matter for behavior matters. Return(ing) is not a matter at hand that should be brushed off, taken into others hands who will bring forth return (ing) as a commodity, which presented by hegemonic powers "is changed into something transcendent."1 5

Walking through Ramallah in Spring 2019 underneath construction and buildings, increasing in height by the year, positioning visions of Prada and Dolce \& Gabbana conveniently located underneath luxury flats. Futures front and center to pedestrians whilst the leadership keeps billboards than the

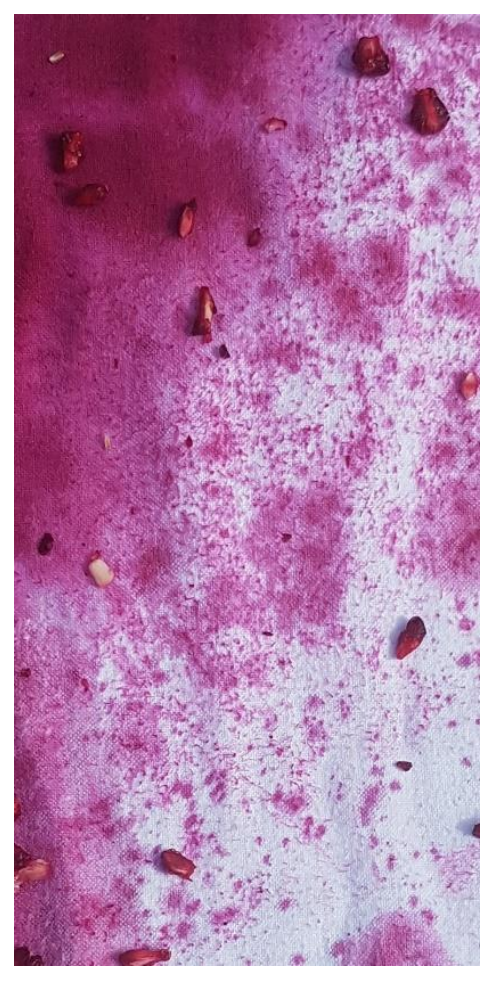
people or streets themselves. These are affects brought forth from the non-queerness of this world.

Couture shops able to exist more easily than the very people who've been here for centuries.

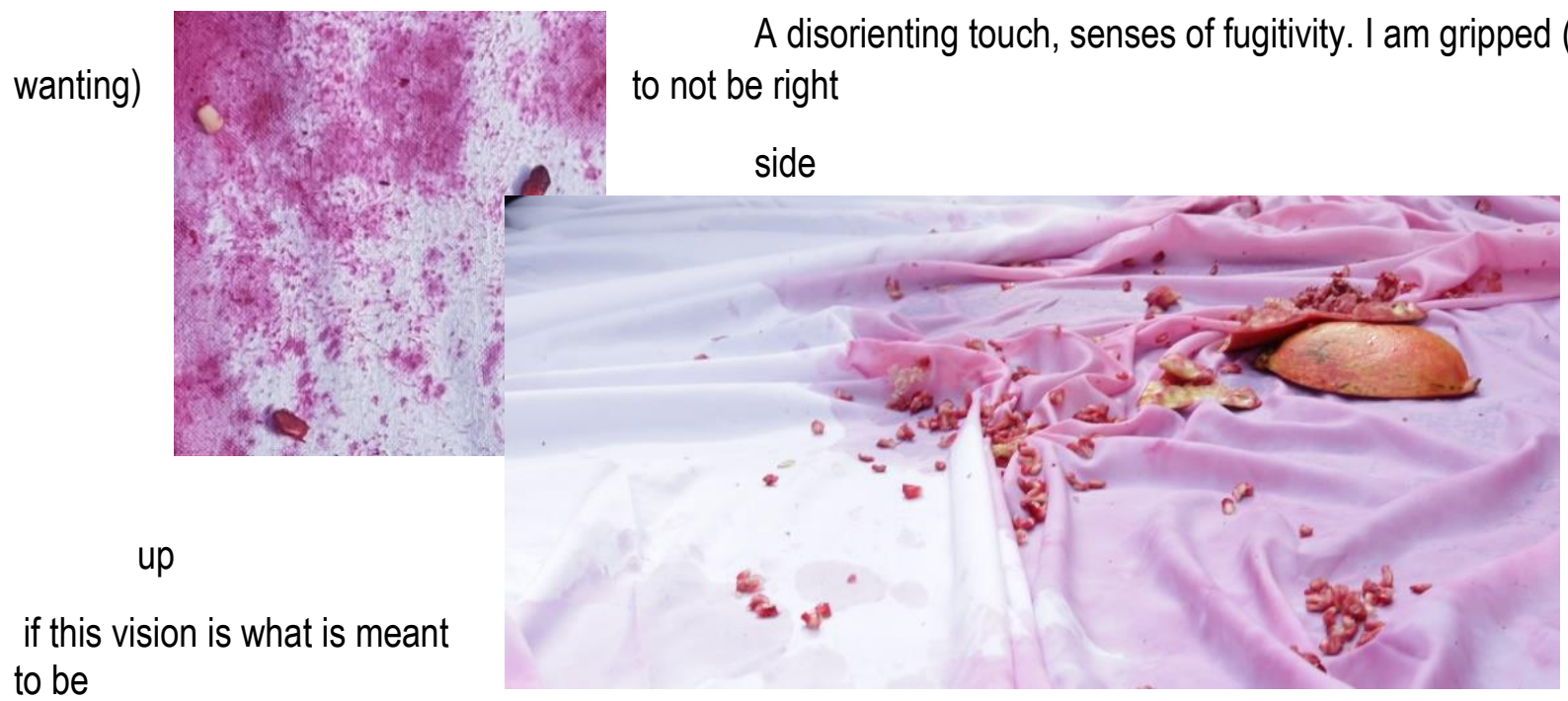

1 lbid. 
the linear perceptible path.

Neoliberal imaginations taking up space, the affects of histories co-opted for state-building as a practice for a return exclusively enjoyed by banks, private investors, newly gated community owners. A commodification of practices shape the form of return - is "it" still return if the very motions that kicked my mother, sister and I out of our home in the states take space in Palestine under a different flag?

Return(ing) is not about trying to find forgiveness/refuge from debt in one boundary only to accumulate it in another. Return(ing) is not about showing solidarity for blackness in one place/language only to arrive to another and allow those very poisoning anti-black articulations/gestures to proliferate in a different tongue.

Return is not something separate from our contact with others; it is a shape made

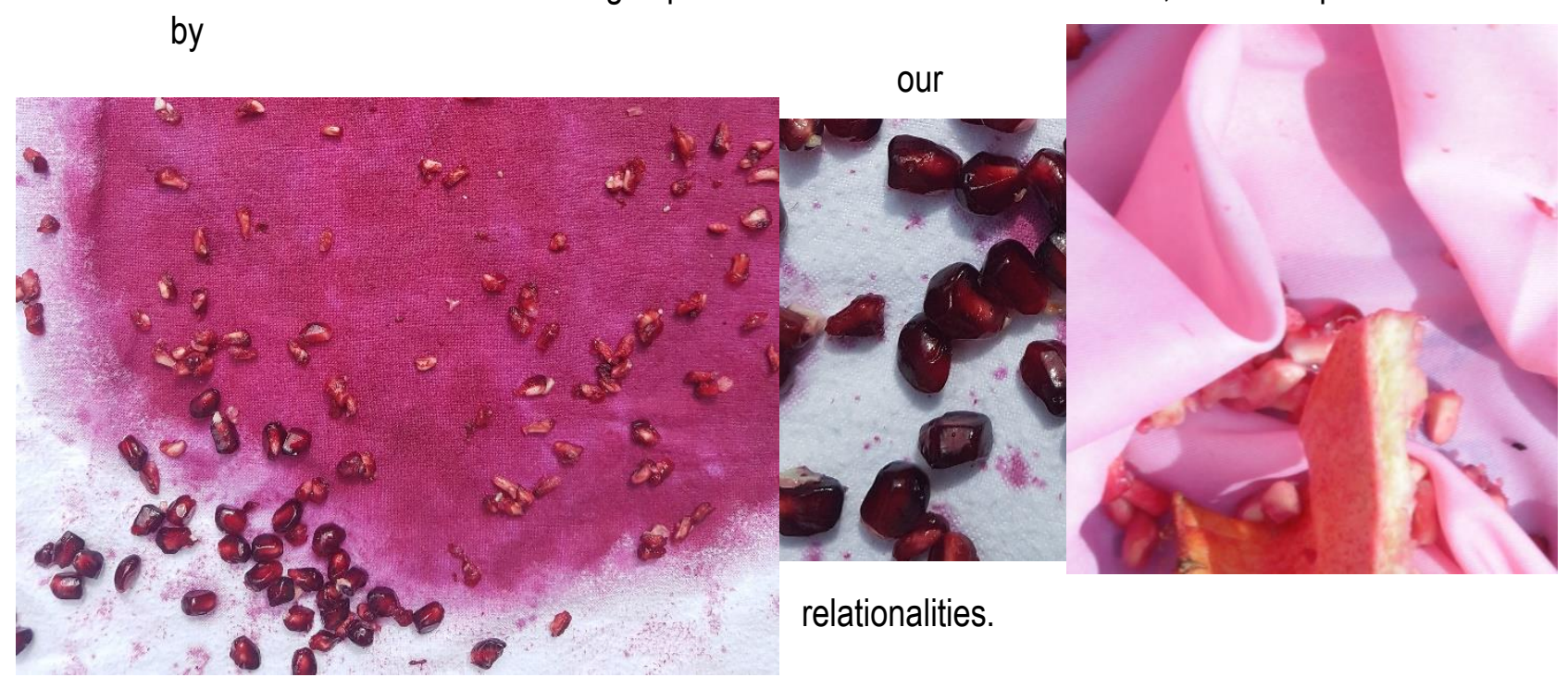

Where am I? Why is this here? What is here and what needs to be in its place?

It is a "queer disorientation, the absence of coherence, but not of things, in the moving presence of absolutely nothing."1 6

It is a hold unlike any other.

Soldiers fire tear gas

i ran holding myself to the sea

washing away the agent only to find our photographs

drowned.

1 Harney, Stefano, and Fred Motenn. 2013. The Undercommons: Fugitive Planning \& Black Study. Wivenhoe: Minor Compositions. 
Understandings of return often arrive at forms of touch/l have a dimension of return for it is a right/ which I am enshrined with by having UN Resolution 194.

The United Nations General Assembly adopts resolution 194 (III), resolving that "refugees wishing to return to their homes and live at peace with their neighbours should be permitted to do so at the earliest practicable date, and that compensation should be paid for the property of those choosing not to return and for loss of or damage to property which, under principles of international law or equity, should be made good by the Governments or authorities responsible." 1

As the UN General Assembly described in the above paragraph in 1948, the emergence of return in this proscribed space and time relies on certain positionalities, certain directions to be taken place. Return must be "practicable," the qualities of this practicable return must be made "good" (for whom?) or compensated (by whose measure?) by the "Governments or authorities responsible" (when has this ever happened?).

Under whose return is this practicable? Nonetheless, "refugees" is left completely unformed - one dimensional. Static. Return emerges as a stack of bones in the corner. Swept aside. Out of sight out of mind. Where is return in any "peace process" resolution, other than the nuisance it presents itself to be the insect on the ground of your kitchen floor scuttling away with the corner of your favorite independence day cake in its mouth.

What position does this interpretation, this practice, this linear, straight state suit making return leave us in? This isn't to dismiss the dire necessity of this dimension of return needing to happen; a physical return especially for those who are experiencing forms limbo for the last several decades. I know all too well the number of spaces my blue U.S.A. passport allows me to breezily walk into - entering the United Kingdom where I currently reside the borders become more insidiously porous through technological aesthetic data harvesting methods. No more do I oftentimes need a person to ask me where I was - I hold a document enshrined with a status which allows me to head straight to machines where I swipe it. Doors open and I walk into a different country. Buying fruits at the self-checkout in Sainsbury's can often feel more like a tedious task than the border. This does not mean I am not direct line of violence - it means the line I am "walking into in that moment, in that space, is extended to me in this particular dimension."

1 UN General Assembly 194 UNRWA https://www.unrwa.org/content/resolution-194

1 Ahmed 2006. 
Are these the forces we leave to shape return? Britain after all has a role in this mess.

I am set in a different direction quite literally from others who hold other documents from other places. And the state sanctifies itself to hold these people differently ---------

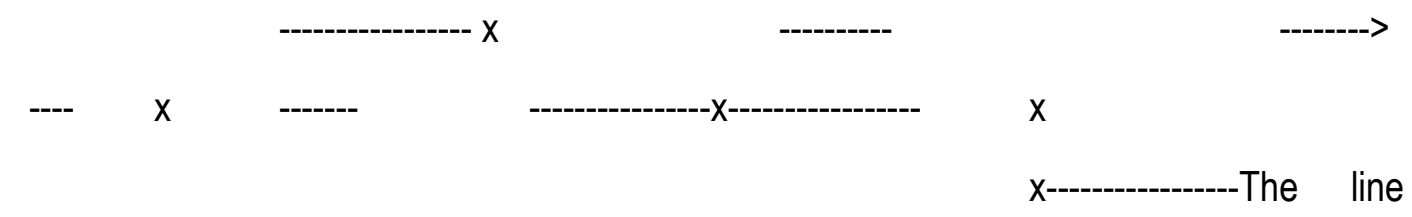

designed to walk within is quite literally straight whereas people who hold "other" documents require more spaces -

to wait

to stand

more cubicles to show the line is

not to be followed without a break but to expect breaks

to expect deviations for you/your (body) becomes the deviation. You become questioned, you become the question in of itself which must be answered - the first curiosity always aligning with that of spatiality

"where have you come from?"

In many ways I hold two molecular embodiments - benefiting from being born in a space which institutionally rejects my very embodiment if I were to be born in the city where my mother was born.

(if someone is denied access to Jerusalem for over 40 years because they are constituted as a threat based solely on their nationality, denied a return, to then be granted a visa after reaching the age of 50 for the state no longer considers this numerological arrival a threat is this deviance restored to a rightful state order? Their being, one day being constituted as a perversion to the state's ethno-sanctity, now being granted permission to be in these certain spatiality - new lines open, new orientations are available, but the texture is still that of the states, of the settler-colonial ordering.)

"And so it is we remain in the hold, in the break, as if entering again and again the broken world, to trace the visionary company and join it."

9

We deviate in our world-making. I remain in this hold - crashing and crashing into this world, shattering and re-shattering to see the fragments and find ways of making new worlds in these profound and heart-wrenching futurisms. "Tracing" as Moten and Stefanno say, the line of deviations, return to spaces we've been to only to find ourselves re-turned. Orientating

1 Harney and Moten 2013.

9 
to others in these visionary lines. I take certain directions to make certain returns - to make those returns/desires seem possible. I align with other's lines if their return(ings)

is a matter of being. Being in return, being returned, be-coming return. It is "the refugee" who needs to be "returned" - a certain position, a deviation from state-making order. Taking it upon ourselves of doing the work to ensure return does not become a commodity.

To own what I am made of/making and what I aim to be, to push forward return as not a single act dictated by hegemonic states, but as pieces of practices encompassing every dimension of life means return is an emancipation of the senses; I push return forward not as a policy which must wait until a linear achievement of Palestinian sovereignty becomes a land form. It is not the end point - it is an ongoing departure. Queering return by re-positioning it as not only a physical dimension of physically returning to Palestine if that is what is chosen by Palestinians, but also occupying multiple times and spaces of practice for Palestinian-ness occupies those very things. I am queering return by facing it as a Palestinian born and raised outside of Palestine - there is a plurality of things within Palestinian-ness which are relegated to the background by hegemonic powers; the starkest example is recognizability of Palestine/Palestinians, including return and also the role of diaspora in world-making.

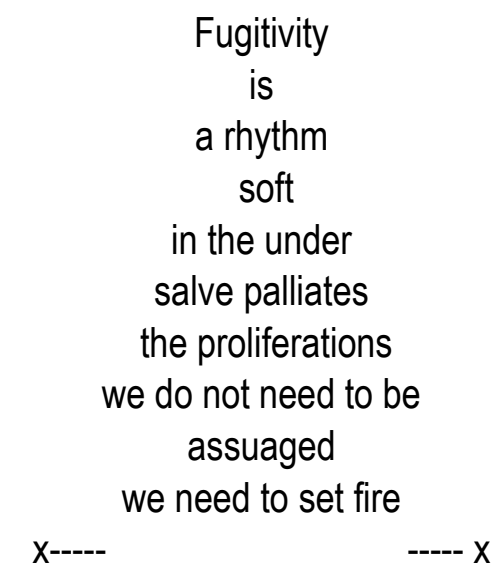

